\title{
Effects of irrigation water salinity and salicylic acid on germination and vigor of Mesosphaerum suaveolens (L.) Kuntze
}

\section{Efeitos da salinidade da água de irrigação e do ácido salicílico na germinação e no vigor de Mesosphaerum suaveolens (L.) Kuntze}

\author{
Jackson Silva Nóbrega ${ }^{1 *}$; Riselane de Lucena Alcântara Bruno ${ }^{2}$; \\ Francisco Romário Andrade Figueiredo ${ }^{3}$; Toshik Iarley da Silva \\ Ronimeire Torres da Silva ${ }^{1}$; Kilson Pinheiro Lopes ${ }^{5}$
}

\section{Highlights:}

Salicylic acid attenuates salinity effects on the initial growth of M. suaveolens.

Seed quality improves with SA priming.

Salicylic acid priming is a promising technique to reduce salinity effects.

\begin{abstract}
Salinity is one of the factors that negatively impact plant growth and productivity; therefore, it is necessary to seek solutions that help mitigate the degenerative action of saline stress on crops. The objective of this study was to evaluate the effects of salicylic acid (SA) on the germination and vigor of Mesosphaerum suaveolens (L.) Kuntze seeds subjected to salinity. The experiment was carried out using a completely randomized design, in an incomplete $5 \times 5$ factorial scheme, with five levels of electrical conductivity of irrigation water ( $\mathrm{ECW}-0.0,1.45,5.00,8.55$, and $\left.10.00 \mathrm{dS} \mathrm{m}^{-1}\right)$ and five doses of SA $(0.0,0.29,1.00,1.71$, and $2.00 \mathrm{mM})$, with four replications of 50 seeds, totaling nine combinations generated via a central composite design. The germination percentage, first germination count, germination speed index, average germination time, percentage of abnormal seedlings, shoot, root, and seedling lengths, and total seedling dry mass were evaluated. Salicylic acid attenuated the effect of saline stress on initial growth, mitigating damage to root and shoot lengths. Seed priming with salicylic acid improved germination and seed vigor.
\end{abstract}

Key words: Medicinal species. Mitigation. Physiological quality. Salinity. Vigor.

\section{Resumo}

A salinidade é um dos fatores que promove a inibição no crescimento e produtividade vegetal, sendo necessária a busca por alternativas que auxiliem na mitigação da ação degenerativa do estresse salino às culturas. Objetivou-se com este trabalho avaliar doses de ácido salicílico na germinação e vigor

1 Discentes do Curso de Doutorado do Programa de Pós-Graduação em Agronomia, Universidade Federal da Paraíba, UFPB, Areia, PB, Brasil. E-mail: jacksonnobrega@hotmail.com; ronimeiretorres@hotmail.com

2 Prof ${ }^{a}$ Dra , Programa de Pós-Graduação em Agronomia, UFPB, Areia, PB, Brasil. E-mail: lanebruno.bruno@gmaail.com

3 Discente do Curso de Doutorado, Programa de Pós-Graduação em Fitotecnia, Universidade Federal Rural do Semi-Árido, UFERSA, Mossoró, RN, Brasil. E-mail: romarioagroecologia@yahoo.com.br

4 Discente de Doutorado do Curso do Programa de Pós-Graduação em Fitotecnia, Universidade Federal de Viçosa, UFV, Viçosa, MG, Brasil. E-mail: iarley.toshik@gmail.com

5 Prof. Dr., Curso de Graduação em Agronomia, Universidade Federal de Campina Grande, UFCG, Pombal, PB, Brasil. E-mail: kilsonlopes@gmail.com

* Autor for correspondence 
de sementes de Mesosphaerum suaveolens (L.) Kuntze submetidas à salinidade. O experimento foi conduzido em delineamento inteiramente casualizado, em esquema fatorial incompleto $5 \times 5$, com cinco níveis de condutividade elétrica da água de irrigação (CEa de 0,$0 ; 1,45 ; 5,00 ; 8,55$ e 10,00 dS m m $^{-1}$ e cinco doses de AS de $\left(0,0 ; 0,29 ; 1,00 ; 1,71\right.$ e $\left.2,00 \mathrm{mM} \mathrm{L}^{-1}\right)$, com quatro repetições de 50 sementes, totalizando nove combinações geradas via matriz Composto Central de Box. As variáveis avaliadas foram: porcentagem de germinação, primeira contagem de germinação, índice de velocidade de germinação, tempo médio de germinação, porcentagem de plântulas anormais, comprimento da parte aérea, radícula e plântula e massa seca total de plântulas. O ácido salicílico atenua o efeito do estresse salino sobre o crescimento inicial, mitigando os danos sobre o comprimento de radícula e da parte aérea. O tratamento das sementes com ácido salicílico melhora a germinação e o vigor das sementes.

Palavras-chave: Espécie medicinal. Mitigação. Qualidade fisiológica. Salinidade. Vigor.

\section{Introduction}

Alfazema-brava (Mesosphaerum suaveolens (L.) Kuntze), belonging to the Lamiaceae family, is found in Tropical America, West Africa, Northern Nigeria, and the Philippines, and is used in a series of applications from all parts of the plant in traditional medicine (Bezerra et al., 2017). It is a species of sub-shrub size found in all states of the Northeast Region of Brazil, presenting leaves with aromatic potential, covered by bristles and glands, small sessile flowers located in the leaf axils and terminal branches of the plant (Sabóia, Barbosa, Parente, \& Parente, 2018). The leaves are rich in secondary compounds such as alkaloids, flavonoids, tannins, saponins, and terpenes, which are used in the pharmaceutical and cosmetics industries, in addition to their use in folk medicine for the treatment of skin diseases, bronchitis, antifungal, and bactericidal action (Alves, Resende, Oliveira, \& Branquinho, 2017).

Although the species has high potential for exploration and excellent adaptability to semi-arid conditions, the growth and development of crops may be limited by the salinity of the soil and water, common in regions such as the Northeast of Brazil. Saline stress affects development in all phases of plants, through osmotic stress, which promotes a reduction in the water absorption capacity by increasing the osmotic potential of the substrate, specific ion toxicity such as $\mathrm{Na}^{+}$and $\mathrm{Cl}^{-}$, nutritional imbalance, and reduction in nutrient absorption (Harter, Harter, Deuner, Meneghello, \& Villela,
2014), resulting in changes in the metabolism and physiology of plants, thereby inhibiting plant growth and early senescence of plants (Negrão, Schmöckel, \& Tester, 2017).

Among the stages of plant development, germination, emergence, and initial seedling growth are the most sensitive to saline stress (E. B. G. Araújo et al., 2016). A high salt content slows or reduces germination and seed vigor, impairing water absorption kinetics, and increasing ion absorption to toxic levels during seed imbibition (Larré, Marini, Moraes, Amarante, \& Moraes, 2014).

The search for mineral and organic inputs that have a mitigating effect on soil and irrigation water salts for sensitive and moderately sensitive plants is increasing in agriculture. Among these compounds, salicylic acid (SA) has shown positive impacts as a phenolic compound that acts in growth regulation, and in plant defense against abiotic stresses such as saline stress (Tonel, Marini, Bandeira, Morais, \& Amarante, 2013; Miura \& Tada, 2014; T. I. Silva et al., 2018). It is involved in the activation and signaling of the expression of genes that participate in the defense mechanisms of the plant, in the photosynthetic process, and in genes that promote the accumulation of reactive oxygen species (ROS) in the apoplast, reducing the intensity of the depressive effects of saline stress (Hasanuzzaman et al., 2014; Mazaro et al., 2015; Sharma et al., 2017). In view of this context and the lack of information on the agronomic characteristics of the species studied, the objective of this study was to evaluate 
the effects of salicylic acid on the germination and vigor of Mesosphaerum suaveolens (L.) Kuntze seeds under saline stress.

\section{Material and Methods}

The experiment was carried out at Laboratório de Análise de Sementes (LAS), at the Centro de Ciências Agrarias, Universidade Federal da Paraíba (CCA/UFPB), Campus II, municipality of Areia, Paraíba. The experiment was carried out using a completely randomized design, in an incomplete 5 $\times 5$ factorial scheme, with five levels of electrical conductivity of irrigation water $(\mathrm{ECw}-0.0,1.45$, $5.00,8.55$, and $\left.10.00 \mathrm{dS} \mathrm{m}^{-1}\right)$ and five doses of SA $(0.0,0.29,1.00,1.71$, and $2.00 \mathrm{mM})$, with four replications of 50 seeds, totaling nine combinations generated via a central composite design (Mateus, Barbin, \& Conagin, 2001).

M. suaveolens seeds were harvested from plants originating from an area of native vegetation, located in the Novo Horizonte settlement, municipality of Várzea, Paraíba. The seeds were processed manually and placed to dry for a period of seven days at room temperature and relative humidity, and then packed in plastic containers and sent to the laboratory for evaluation of physiological quality.

The water content of seeds was determined by the air-circulation oven method at $105 \pm 3{ }^{\circ} \mathrm{C}$ for 24 $\mathrm{h}$, with four repetitions of $5 \mathrm{~g}$ of seeds (Ministério da Agricultura, Pecuária e Abastecimento [MAPA], 2009).

The saline solutions were prepared using sodium chloride $(\mathrm{NaCl})$, free of iodine with $92 \%$ purity, diluted in distilled water in the proportions needed to produce the electrical conductivity values previously stipulated, and measured with a portable conductivity meter (CD-860). The doses of salicylic acid were prepared by diluting in $200 \mathrm{~mL}$ of distilled water. The seeds were soaked in the SA solutions for $8 \mathrm{~h}$ in plastic containers covered with aluminum foil and kept at room temperature and relative humidity. The seeds were then washed with distilled water to remove excess salicylic acid, and germination and seed vigor tests were carried out.

Germination was carried out in a germination chamber (biochemical oxygen demand (BOD) type) regulated at a constant temperature of $25^{\circ} \mathrm{C}$ and a photoperiod of $8 \mathrm{~h}$, using a sheet of Germitest ${ }^{\circledR}$ paper as a substrate, moistened with the saline solutions at a volume 2.5 times the mass of the dry paper. Germination was evaluated from the $4^{\text {th }}$ to the $15^{\text {th }}$ day after the start of the experiment. The results were expressed as a percentage of normal seedlings (MAPA, 2009), with a normal seedling being considered as one with both a root protrusion and leaf primordia present.

The first germination count was determined by counting the number of seeds that had germinated on the $4^{\text {th }}$ day after the beginning of the experiment. The germination speed index was determined by counting the number of seeds germinated on each specific day, according to the formula proposed by Maguire (1962). The average germination time was established from daily counts of the number of seeds germinated using the formula of Labouriau (1983). Abnormal seedlings were recorded from the count on the $15^{\text {th }}$ day after the experiment was initiated (MAPA, 2009).

At 15 days after the start of the experiment, radicle and shoot seedling lengths were measured with a graduated ruler. At the end of the experiment, the dry mass of the seedlings was quantified, seedlings were packed in Kraft paper bags, and dried in an oven with forced air circulation at $65^{\circ} \mathrm{C}$ until they reached a constant dry mass obtained in a precision analytical balance $(0.0001 \mathrm{~g})$.

The data were subjected to analysis of variance by the $\mathrm{F}$ test at $5 \%$ probability, and in cases of a significant effect, a regression analysis was then applied. The data with the effect for the interaction between the factors were presented by means of the response surface and those isolated by linear or quadratic regression. The statistical program used for data processing was SAS University (Cody, 2015). 


\section{Results and Discussion}

The seeds, before undergoing priming with SA, had an initial water content of $9.7 \%$, and therefore were within the tolerable limit for maintaining the seeds physiological quality, which must be equal to or less than $12 \%$ (Oliveira, Schuch, Bruno, \& Peske, 2015).
Our results indicate a significant effect for the interaction between the factors studied for the radicle and shoot lengths (Table 1). Priming with SA had an isolated effect on the percentage of germination, first count of germination, germination speed index, average germination time, and seedling length. $\mathrm{ECW}$ did not affect the quality of $M$. suaveolens seeds (Table 1).

Table 1

Average values of the summary of the analysis of variance for germination (G\%), first germination count (FGC), germination speed index (GSI), average germination time (AGT), abnormal seedlings (AS), radicle length (RL), shoot length (SL), seedling length (SEL) and seedlings dry mass (SDM) of Mesosphaerum suaveolens (L.) Kuntze seedlings subjected to doses of salicylic acid and salinity of irrigation water

\begin{tabular}{|c|c|c|c|c|c|c|}
\hline \multirow{2}{*}{ SV } & \multirow{2}{*}{ DF } & \multicolumn{5}{|c|}{ Mean square } \\
\hline & & G(\%) & FGC & & GSI & AGT \\
\hline SA & 1 & $2527.78 * *$ & $1605.44 * *$ & & $50.33^{* *}$ & $0.002^{\text {ns }}$ \\
\hline $\mathrm{ECw}$ & 1 & $145.09^{\mathrm{ns}}$ & $5.93^{\mathrm{ns}}$ & & $0.82^{\mathrm{ns}}$ & $0.90^{\text {ns }}$ \\
\hline $\mathrm{SA} * \mathrm{SA}$ & 1 & $1048.44 *$ & $7321.11 * *$ & & $108.77 * *$ & $23.14^{* *}$ \\
\hline $\mathrm{ECw}^{*} \mathrm{ECw}$ & 1 & $41.80^{\mathrm{ns}}$ & $219.32^{\mathrm{ns}}$ & & $1.64^{\mathrm{ns}}$ & $0.052^{\mathrm{ns}}$ \\
\hline $\mathrm{SA} * \mathrm{ECw}$ & 1 & $64.00^{\mathrm{ns}}$ & $144.00^{\text {ns }}$ & & $0.36^{\mathrm{ns}}$ & $1.19^{\mathrm{ns}}$ \\
\hline Residue & 24 & 141.74 & 127.11 & & 2.49 & 0.36 \\
\hline \multirow[t]{2}{*}{ CV (\%) } & & 19.1 & 30.2 & & 19.85 & 13.23 \\
\hline & & AS & $\mathrm{RL}$ & SL & SEL & SDM \\
\hline SA & 1 & $6.15^{\text {ns }}$ & $1.95 * *$ & $0.26^{\mathrm{ns}}$ & $3.65 * *$ & $1.7253 \mathrm{E}-08^{\mathrm{ns}}$ \\
\hline $\mathrm{ECw}$ & 1 & $38.22 *$ & $0.79 *$ & $2.34 * *$ & $0.41^{\mathrm{ns}}$ & $1.7348 \mathrm{E}-09^{\mathrm{ns}}$ \\
\hline $\mathrm{SA} * \mathrm{SA}$ & 1 & $0.57^{\mathrm{ns}}$ & $2.94 * *$ & $0.79 *$ & $0.68^{\mathrm{ns}}$ & $1.2058 \mathrm{E}-06^{\mathrm{ns}}$ \\
\hline $\mathrm{ECw}^{*} \mathrm{ECw}$ & 1 & $2.54^{\mathrm{ns}}$ & $0.39^{\text {ns }}$ & $3.41^{* *}$ & $1.50^{\mathrm{ns}}$ & $3.0344 \mathrm{E}-06^{\mathrm{ns}}$ \\
\hline $\mathrm{SA} * \mathrm{ECW}$ & 1 & $2.25^{\text {ns }}$ & $2.24 * *$ & $1.16^{* *}$ & $0.18^{\mathrm{ns}}$ & $1.1775 \mathrm{E}-06^{\mathrm{ns}}$ \\
\hline Residue & 24 & 6.38 & 0.19 & 0.11 & 0.45 & $7.4000 \mathrm{E}-07$ \\
\hline CV (\%) & & 108.1 & 12.7 & 13.6 & 11.5 & 45.8 \\
\hline
\end{tabular}

We concluded that $M$. suaveolens has a high tolerance to salinity as there was no reduction in seed quality with the increase in salinity. It has resistance to stress conditions such as salinity, managing even under adverse conditions to maintain the ability to germinate and survive, possibly because this species has an excellent ability to adapt to semi-arid environments. Species with high rusticity tend to have high genetic variability, providing the ability to adjust osmotically to stressful environments, enabling their survival even in adverse situations (Dolferus, 2014).

The interaction between salicylic acid doses and irrigation water salinity significantly affected both radicle and shoot lengths (Figure 1). 

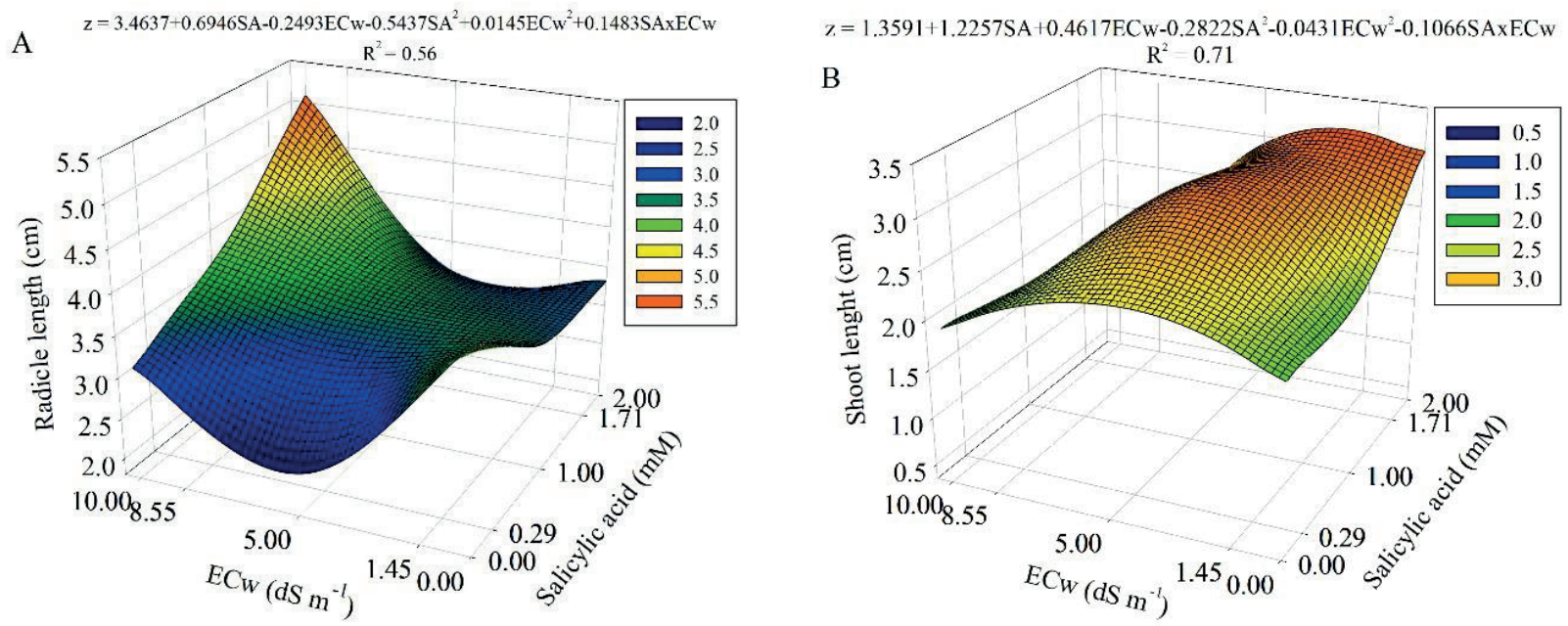

Figure 1. Radicle length (A) and shoot lenght (B) of Mesosphaerum suaveolens (L.) Kuntze seedlings submitted to doses of salicylic acid and salinity of irrigation water (ECw).

The greatest radicle length $(4.59 \mathrm{~cm})$ was obtained in seedlings subjected to an ECw of 9.96 $\mathrm{dS} \mathrm{m}^{-1}$ and $1.97 \mathrm{mM}$ SA (Figure 1A). Salicylic acid regulates plant growth, acting on signaling and defense mechanisms against stress conditions (Miura \& Tada, 2014), thereby promoting gene expression and the production and accumulation of osmoprotective substances that induce greater tolerance to salt stress (Kamram et al., 2020). Thus, as a defense mechanism, SA promotes changes in gene expression and proteins involved in the homeostasis of plants under stress, providing greater resistance to salinity (Csiszár et al., 2018).

The largest shoot length $(3.1 \mathrm{~cm})$ was in a treatment with $\mathrm{ECw}$ of $3.48 \mathrm{dS} \mathrm{m}^{-1}$ and $1.51 \mathrm{mM}$ of SA (Figure 1B). The application of SA contributes to reducing the deleterious effects of toxic ions on plants up to the $\mathrm{ECw}$ of $5 \mathrm{dS} \mathrm{m} \mathrm{m}^{-1}$, enabling greater shoot growth, and consequently producing more vigorous seedlings. Salicylic acid can act by regulating the absorption and translocation of ions from the root to the shoot by excluding and retaining low or high levels of $\mathrm{Na}^{+}$in the roots and preventing it from being transported to the shoot (Methenni et al., 2018).

Salicylic acid promoted an isolated effect on germination variables, including first germination count, germination speed index, average germination time, and seedling length. The increase in SA doses linearly increased the percentage of seed germination from 49.31 to $78.56 \%$ with a $59.3 \%$ superiority between treatments without and with $2.00 \mathrm{mM}$ of SA (Figure 2A). 

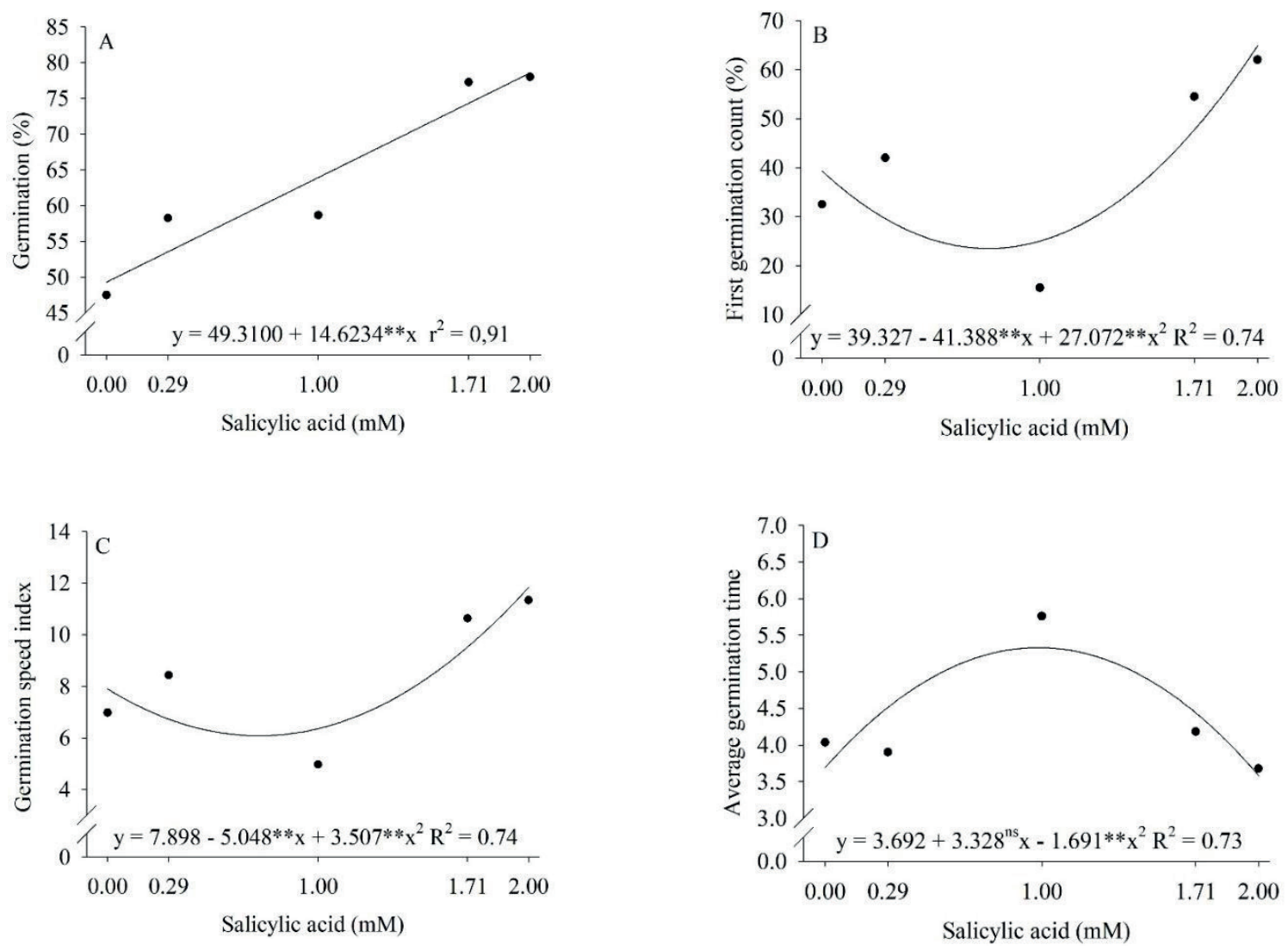

Figure 2. Germination (A), first germination count (B), germination speed index (C) and average germination time (D) of Mesosphaerum suaveolens (L.) Kuntz submitted to doses of salicylic acid.

This effect may be due to the stimulus promoted by $\mathrm{SA}$ in the expression of genes involved in germination, resulting in an increase in seedling quality. It is possible that SA induced the mobilization of starch and the activity of the enzyme amylase, favoring a greater supply of energy to growth of the embryonic axis, stimulating germination and cell integrity (Bouallègue et al., 2017).

In terms of seed vigor, represented by first germination count, SA initially delayed the germination process of seeds, with a reduction from $39.33 \%$ to $23.51 \%$ and a decrease of $40.2 \%$ between treatments with and without $0.76 \mathrm{mM}$ SA. The application of SA above the minimum estimated dose however had an effect similar to that registered in Figure 2A; that is, it increased the seed germination count from $23.51 \%$ to $64.84 \%$ in the 2.0 mM SA, surpassing by $175.80 \%$ the germination of seeds treated with $0.76 \mathrm{mM}$ of the respective input (Figure 2B). This increase concurs with Anaya, Fghire, Wahbi and Loufi (2018), who demonstrated a positive effect of salicylic acid at a dosage of 0.25 $\mathrm{mM}$ in the germination of fava bean (Vicia faba L.) seeds. The exogenous application of SA in seeds promotes the expression and signaling of genes that act on the properties of the cell membrane, resulting in greater production of phenolic compounds that can enhance the seeds with greater germination capacity (Tonel et al., 2013; T. I. Silva et al., 2018).

As with the first germinated seed count (Figure 2B), the increase in SA dose initially inhibited the germination speed index (GSI; Figure 2C) from 7.9 to 6.1 , causing a $22.8 \%$ decline between seeds without and with $0.72 \mathrm{mM} \mathrm{SA}$. On the other hand, applications above $0.72 \mathrm{mM}$ increased the GSI to a maximum value of 11.8 , inducing an increase of 
93.4\% with a dose of $2 \mathrm{mM}$. As it is considered a growth regulator, SA can stimulate both the germination process and seed vigor, resulting in a faster germination process. Salicylic acid acts by regulating plant growth, acting on the physiological processes associated with germination and growth, reducing the harmful effects promoted by abiotic stresses, including salinity and defense mechanisms (E. D. Araújo, Melo, Rocha, Carneiro, \& Rocha, 2018).

Salicylic acid initially delayed seed germination from 3.7 to 5.3 days at the estimated dose of 1.00 $\mathrm{mM}$, leading to a delay of 1.6 days (Figure 2D). However, the increase in SA above the estimated dose accelerated the germination process, reducing the period for germination from 5.3 to 3.6 days between the seeds in the estimated dose and the maximum applied. Salicylic acid at doses up to
$1.00 \mathrm{mM}$ has an inhibitory effect on germination, stimulating the appearance of biochemical changes such as the activity of acid phosphatase enzymes, $\alpha$-amylase, and the content of seed reserves (Silveira, Moraes, \& Lopes, 2000; T. C. F. S. Silva et al., 2014).

Although SA slows down the germination process, at doses up to $1.00 \mathrm{mM}$, it linearly stimulated the height growth of seedlings at a level of $0.52 \mathrm{~cm}$ by increasing the unit concentration (Figure 3A). The values increased from 5.2 to 6.3 $\mathrm{cm}$ with a $21.2 \%$ superiority between seedlings without and with $2.0 \mathrm{mM}$ of SA. The positive action of SA in plant growth regulation is due to the stimulation of cell expansion and division in different phases (Ghassemi-Golezani \& FarhangiAbriz, 2018; Nóbrega et al., 2018a).
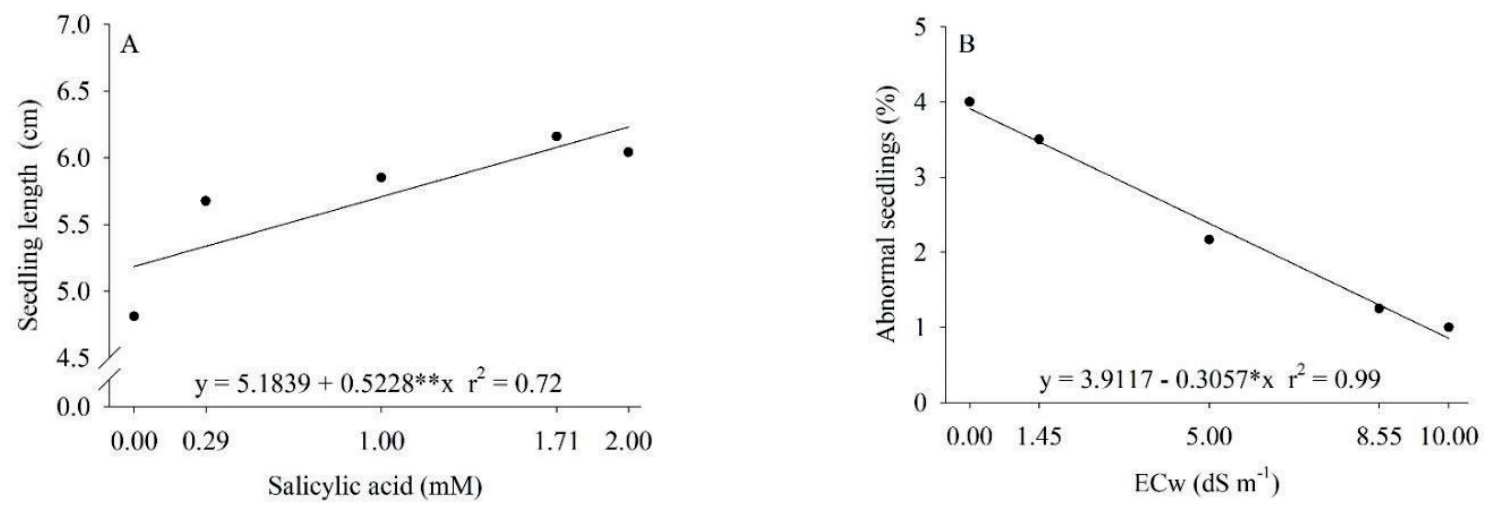

Figure 3. Seedling length submitted to different doses of salicylic acid (A) and percentage of abnormal seedlings (B) of Mesosphaerum suaveolens (L.) Kuntze as a function of irrigation water salinity (ECw).

The increase in water salinity linearly inhibited the occurrence of abnormal seedlings (Figure 3B). This positive quality can be both a biological response to saline stress, stimulating the achievement of normal seedlings, and due to the rusticity of the species in tolerating a high level of saline stress. Thus, its high rusticity provides greater ability to promote osmotic adjustment to the adverse effects of salinity, enabling survival in adverse conditions (Nóbrega et al., 2018b).
This effect has been reported in other species with a high degree of rusticity such as cucumber melon (Cucumis melo var. Cantalupensis Naud), in which an $\mathrm{ECw}$ of $8.0 \mathrm{dS} \mathrm{m} \mathrm{m}^{-1}$ stimulated the germination process and the achievement of normal seedlings (Nóbrega et al., 2018b). In pepper var. SAL-Surjomukhi, a salinity of $2.0 \mathrm{dS} \mathrm{m}^{-1}$ promoted a $33.6 \%$ increase in germination compared to the control treatment (Jamal Uddin, Hasan, Rahul, Mahbuba, \& Ahmad, 2017). 


\section{Conclusions}

Seed priming with salicylic acid increases germination and seed vigor, represented by the tests of first count of germination, germination speed index, average germination time, and seedling length of $M$. suaveolens. Salicylic acid was efficient in mitigating the harmful effects caused by saline stress, promoting the production of more vigorous M. suaveolens seedlings.

\section{Acknowledgments}

Coordenação de Aperfeiçoamento de Pessoal de Nível Superior (CAPES) is thanked for granting scholarships and research funding.

\section{References}

Alves, J. J. L., Resende, O., Oliveira, D. E. C., \& Branquinho, N. A. A. (2017). Cinética de secagem das folhas de Hyptis suaveolens. Revista Brasileira de Plantas Medicinais, 19(2), 168-176. doi: 10.1590/1983-084X/0013

Anaya, F., Fghire, R., Wahbi, S., \& Loufi, K. (2018). Influence of salicylic acid on seed germination of Vicia faba L. under salt stress. Journal of the Saudi Society of Agricultural Science, 17(1), 1-8. doi: 10.1016/j.jssas.2015.10.002

Araújo, E. B. G., Sá, F. V. S., Oliveira, F. A., Souto, L. S., Paiva, E. P., Silva, M. K. N.,... Brito, M. E. B. (2016). Crescimento inicial e tolerância de cultivares de meloeiro à salinidade da água. Revista Ambiente e Água, 11(2), 462-471. doi: 10.4136/1980-993X

Araújo, E. D., Melo, A. S., Rocha, M. S., Carneiro, R. F., \& Rocha, M. M. (2018). Germination and initial growth of cowpea cultivars under osmotic stress and salicylic acid. Revista Caatinga, 31(1), 80-89. doi: 10.1590/1983-21252018v31n110rc

Bezerra, J. W. A., Costa, A. R., Silva, M. A. P., Rocha, M. I., Boligon, A. A., Rocha, J. B. T.,... Kamdem, J. P. (2017). Chemical composition and toxicological evaluation of Hyptis suaveolens (L.) Poiteau (LAMIACEAE) in Drosophila melanogaster and Artemia salina. South African Journal of Botany, 113(1), 437-442. doi: 10.1016/j.sajb.2017.10.003

Bouallègue, A., Souissi, F., Nouairi, I., Souibgui, M., Abbes, Z., \& Mhadhbi, H. (2017). Salicylic acid and hydrogen peroxide pretreatments alleviate salt stress in faba bean (Vicia faba) seeds during germination. Seed Science and Technology, 45(3), 675-690. doi: 10.15258/sst.2017.45.3.07

Cody, R. (2015). An introduction to SAS University Edition. Cary: SAS Institute.

Csiszár, J., Brunner, S., Horváth, E., Bela, K., Ködmön, P., Riyazuddin, R.,... Tari, I. (2018). Exogenously applied salicylic acid maintains redox homeostasis in salt-stressed Arabidopsis gr1 mutants expressing cytosolic roGFP1. Plant Growth Regulation, 86(2), 1-14. doi: 10.1007/s10725-018-0420-6

Dolferus, R. (2014). To grow or not to grow: a stressful decision for plants. Plant Science, 229(1), 247-261. doi: 10.1016/j.plantsci.2014.10.002

Ghassemi-Golezani, K., \& Farhangi-Abriz, S. (2018). Changes in oil accumulation and fatty acid composition of soybean seeds under salt stress in response to salicylic acid and jasmonic acid. Russian Journal of Plant Physiology, 65(2), 229-236. doi: 10.1134/S1021443718020115

Harter, L. S. H., Harter, F. S., Deuner, C., Meneghello, G. E., \& Villela, F. A. (2014). Salinidade e desempenho fisiológico de sementes e plântulas de mogango. Horticultura Brasileira, 32(1), 80-85. doi: 10.1590/ S0102-05362014000100013

Hasanuzzaman, M., Alam, M. M., Nahar, K., AlMahmud, J., Ahamed, K. U., \& Fujita, M. (2014). Exogenous salicylic acid alleviates salt-stress oxidative damage in Brassica napes by enhancing the anti oxidant defense and glyoxalase systems. Australian Journal of Crop Science, 8(4), 631648. Recuperado em: http://www.cropj.com/ hasanuzaman_8_4_2014_631_639.pdf

Jamal Uddin, A. F. M., Hasan, M. R., Rahul, S. K., Mahbuba, S., \& Ahmad, H. (2017). NaCl priming levels on germination and seedling development of chilli under saline condition. International Journal of Business, Social and Scientific Research, 5(2), 175179. Recuperado em: http://www.ijbssr.com/journal/ detailsview/nacl-priming-levels-on-germinationand-seedling-development-of-chilli-under-salinecondition-14013197.

Kamram, M., Xie, K., Sun, J., Wang, D., Shi, C., Lu, Y.,... $\mathrm{Xu}$, P. (2020). Modulation of growth performance and coordinated induction of ascorbate-glutathione and methylglyoxal detoxification systems by salicylic acid mitigates salt toxicity in choysum (Brassica parachinensis L.). Ecotoxicology and Environmental Safety, 188(1), 109877. doi: 10.1016/j.ecoenv.2019.109877 
Labouriau, L. G. (1983). A germinação das sementes. Washington: Secretaria da OEA.

Larré, C. F., Marini, P., Moraes, C. L., Amarante, L., \& Moraes, D. M. (2014). Influência do 24-epibrassinolídeo na tolerância ao estresse salino em plântulas de arroz. Semina: Ciências Agrárias, 35(1), 67-76. doi: 10.5433/1679-0359.2014v35n1p6

Maguire, J. D. (1962). Speed of germination-aid in selection and evaluation for seedling emergence vigor. Crop Science, 2(2), 176-177. doi: 10.2135/cro psci1962.0011183X000200020033x

Ministério da Agricultura, Pecuária e Abastecimento (2009). Regras para análise de sementes. Secretaria Nacional de Defesa Agropecuária. Brasília: MAPA/ ACS.

Mateus, N. B., Barbin, D., \& Conagin, A. (2001). Viabilidade de uso do delineamento composto central. Acta Scientiarum, 23(6), 1537-1546. doi: 10.4024/actascitechnol.v23i0.2795

Mazaro, S. M., Borsatti, F. C., Dalacosta, N. L., Lewandowski, A., Danner, M. A., Busso, C., \& Wagner, A., Jr. (2015). Qualidade pós-colheita de acerolas tratadas com ácido salicílico. Revista Brasileira de Ciências Agrárias, 10(4), 512-517. doi: 10.5039/agraria.v10i4a519

Methenni, K., Abdallah, M. B., Nouairi, I., Smaoui, A., Ammar, W. B., Zarrouk, M., \& Youssef, N. B. (2018). Salicylic acid and calcium pretreatments alleviate the toxic effect of salinity in the Oueslati olive variety. Scientia Horticulturae, 233(1), 349358. doi: $10.1016 /$ j.scienta.2018.01.060

Miura, K., \& Tada, Y. (2014). Regulation of water, salinity, and cold stress responses by salicylic acid. Frontiers in Plant Science, 5(1), 4. doi: 10.3389/ fpls.2014.00004

Negrão, S., Schmöckel, S. M., \& Tester, M. (2017). Evaluating physiological responses of plants to salinity stress. Annals of Botany, 119(1), 1-11. doi: 10.1093/aob/mcw191

Nóbrega, J. S., Figueiredo, F. R. A., Nascimento, R. G. S., Bruno, R. L. A., Alves, E. U., \& Cavalcante, L. F. (2018b). Qualidade fisiológica de sementes de melão pepino sob salinidade crescente da água de irrigação. Revista de Ciências Agrárias, 41(4), 1011-1018. doi: 10.19084/RCA18146
Nóbrega, J. S., Figueiredo, F. R. A., Sousa, L. V., Ribeiro, J. E. S., Silva, T. I., Dias, T. J.,... Bruno, R. L. A. (2018a). Effect of salicylic acid on the physiological quality of salt-stressed Cucumis melo seeds. Journal of Experimental Agriculture International, 23(6), 1-10. doi: 10.9734/JEAI/2018/41811

Oliveira, L. M., Schuch, L. O. B., Bruno, R. L. A., \& Peske, S. T. (2015). Qualidade de sementes de feijãocaupi tratadas com produtos químicos e armazenadas em condições controladas e não controladas de temperatura e umidade. Semina: Ciências Agrárias, 36(3), 1263-1276. doi: 10.5433/1679-0359.2015v36 n3p 1263

Sabóia, C. M., Barbosa, T. S., Parente, K. M. S., \& Parente, E. G., F $F^{o}$. (2018). Efeito alelopático de extratos de folhas frescas de bamburral (Hyptis suaveolens L.) sobre a germinação e o desenvolvimento de plântulas de pepino (Cucumis sativus L.). Revista Fitos, 12(1), 18-26. doi: 10.5935/2446-4775.20180003

Sharma, M., Gupta, S. K., Majumder, B., Maurya, V. K., Deeba, F., Alam, A., \& Pandey, V. (2017). Salicylic acid mediated growth, physiological and proteomic responses in two wheat varieties under drought stress. Journal of Proteomics, 163(1), 28-51. doi: 10.1016/j.jprot.2017.05.011

Silva, T. C. F. S., Silva, R. C. B., Silva, J. E. S. B., Santos, R. S., Aragão, C. A., \& Dantas, B. F. (2014). Germinação de sementes de melancia sob diferentes métodos de tratamento com reguladores vegetais. Scientia Plena, 10(3), 1-15. Recuperado em: https:// www.scientiaplena.org.br/sp/article/view/1794/944

Silva, T. I., Nóbrega, J. S., Figueiredo, F. R. A., Sousa, L. V., Ribeiro, J. E. S., Bruno, R. L. A.,... Albuquerque, M. B. (2018). Ocimum basilicum L. seeds quality as submitted to saline stress and salicylic acid. Journal of Agricultural Science, 10(5), 159-166. doi: $10.5539 /$ jas.v10n5p159

Silveira, M. A. M., Moraes, D. M., \& Lopes, N. F. (2000). Germinação e alterações bioquímicas em sementes de arroz tratadas com ácido salicílico. Revista Brasileira de Sementes, 22(2), 200-205. doi: 10.17801/0101-3122/rbs.v22n2p200-205.

Tonel, F. R., Marini, P., Bandeira, J. M., Morais, D. M., \& Amarante, L. (2013). Salicylic acid: physiological and biochemical changes in seeds and maize seedlings subjected to salt stress. Journal of Seed Science, 35(4), 457-465. doi: 10.1590/S231715372013000400007 
